\title{
legelivet
}

På disse sidene i Tidsskriftet - legelivet - finner du stoff om legers liv.

Her er det presentasjon av arbeidssteder, nyhetssaker, nye doktorgrader,

nye spesialister og minneord. Alt samlet på ett sted - så du kan følge enda bedre med.

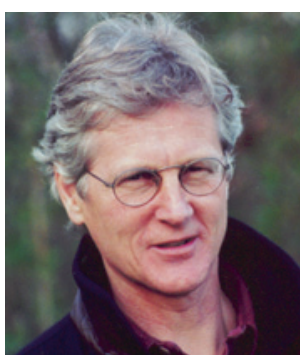

Karl Otto Nakken

Foto: Privat

Karl Otto Nakken (f. 1945) er lege ved Nevroklinikken, Oslo universitetssykehus.

«Det eneste vi egentlig har til felles, er himmelen over våre hoder»

\section{Refleksjoner fra doktorklubben}

\author{
Etter en kveld i doktorklubben ble jeg sittende og reflektere over hvor \\ forskjellige vi i grunnen er. Var det slik i utgangspunktet, eller er vi blitt \\ preget av fagfeltene vi har jobbet i?
}

Molekylærbiologen og barnepsykiateren har nok hatt svært forskjellige legeliv. Enkelte ganger tenker jeg at det eneste vi egentlig har til felles, er himmelen over våre hoder.

Men så kommer jeg på én ting, nemlig gleden over å få kollegene til å smile og le. Vår humor er gjerne basert på pussige sykehushistorier, sementerte fordommer og litt godlynt mobbing. Vi kan også ha hissige helsepolitiske diskusjoner, der komplekse problemer ofte får enkle løsninger. Noen er mer skråsikre og dominante enn andre, og som tviler kan jeg til tider oppleve et obstfeldersk utenforskap. Mine spede forsøk på å få i gang noen filosofisk pregede diskusjoner faller som regel på steingrunn. Hva skal man si når jeg spør: Hvor kommer vi fra, og hvor går vi hen? Og får som svar henholdsvis Grefsen og Skillebekk?

Vi tok doktorskolen sammen i Oslo $\mathrm{i}$ årene 1965-71. Jeg kan huske at universitetet lokket oss med at vi her ville få varig vekkede sjelsevner. Etter hvert fikk vi da også stor nysgjerrighet og appetitt på faget.
Ingen av oss var noen rabulistiske 68-ere. Gjennom hele studietiden delte vi sorger og gleder over så vel eksamensresultater som romanser. Et kjærkomment fellesskap for tanker og betroelser.

Som ved de fleste studentkull hadde også vi enkelte som fra første benk stadig avbrøt foreleserne med spørsmål av typen «professor, er det ikke slik at..?». Dette til stor irritasjon for så vel foreleser som medstudenter. Det fortelles en historie om en slik student, la meg kalle ham Hansen, som under en forelesning til den legendariske nevrologen Georg Monrad Krohn (1884-1964) stilte følgende spørsmål: «Si meg, professor, hvor lenge kan et menneske leve uten noen form for hjerneaktivitet?» Til stor munterhet for medstudentene svarte Monrad at «i Deres tilfelle, Hansen, må vi nok bare vente og se».

Om historien er sann, vet jeg ikke. Men i doktorklubben er vi enige om at sannheten aldri må få stå i veien for en god historie.

Karl Otto Nakken karln@ous-hf.no 